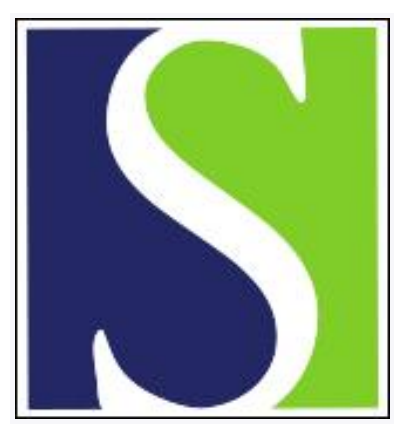

Scand J Work Environ Health 1981;7(3):179-184

https://doi.org/10.5271/sjweh.3108

Issue date: Sep 1981

A cohort study on cancer among workers exposed to an antirust oil

by Järvholm B, Lavenius B

Affiliation: Department of Occupational Medicine, Sahlgrenska Sjukhuset, S-413 45 Goteborg, Sweden.

The following article refers to this text: 1986;12(5):512

Key terms: antirust oil; cancer; cohort study; epidemiology; exposure; $\mathrm{N}$-nitrosoamine; N-phenyl-1-naphthylamine; sodium nitrite; worker

This article in PubMed: www.ncbi.nlm.nih.gov/pubmed/20120582

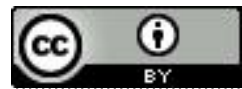




\title{
A cohort study on cancer among workers exposed to an antirust oil
}

\author{
by Bengt Järvholm, MD, ${ }^{1}$ Bengt Lavenius, $\mathrm{MD}^{2}$
}

\begin{abstract}
JÄRVHOLM B, LAVENIUS B. A cohort study on cancer among workers exposed to an antirust oil. Scand $j$ work environ health 7 (1981) 179-184. An epidemiologic study in an engineering company was prompted by the observation of three cases of cancer; it revealed several more cancers among women who wrapped bearing rings covered with antirust oil, ie, 12 cases vs 3.9 expected. The 12 tumors were situated in different organs, including the uterus, ovaries, breast, thyroid, brain, colon, and bladder. No known carcinogenic substance was found that could explain the increased incidence of cancer. If the increased incidence is not a random phenomenon, N-phenyl-1naphthylamine or its nitroso derivative is likely to be the causative agent.
\end{abstract}

Key terms: epidemiology, N-nitrosoamines, N-phenyl-1-naphthylamine, sodium nitrite.

Over the years there has been concern about cancer hazards from various industrial chemicals, among them oils with various contaminants and additives. Therefore, when it was reported that three cases of cancer had occurred among the personnel in a rather small department where bearing rings covered with antirust oil were wrapped, this study was initiated to delineate further the mortality pattern among the employees. A survey of the production revealed that during the years $1954-1957$ a special antirust oil had been commonly used in this department, but only exceptionally elsewhere in the company. The suspicion arose that this specific oil, alone or in combination with something else, might have caused an increased incidence of cancer, since already three cases seemed to be more than should occur in a few years in a rather small group of workers.

1 Department of Occupational Medicine, Sahlgrenska Sjukhuset, Göteborg, Sweden.

2 Health Department, AB SKF, Göteborg, Sweden.

Reprint requests to: Dr B Järvholm, Department of Occupational Medicine, Sahlgrenska Sjukhuset, S-413 45 Göteborg, Sweden.

\section{Subjects and methods}

By means of the personnel register all those individuals were identified who had worked at any time between 1954 and 1957 in the department where the three original cases of cancer were observed and where the specific oil had been used (group A). In the same way, referents were obtained from another packing department where the specific oil not had been used (group B). The antirust oil had also been used at some other workplaces within the company, and some individuals were sensitized briefly after its introduction in 1954. Those who became sensitized and had medical treatment for eczema were registered in 1955 and entered on a list. These individuals from various departments were tested by a dermatologist in 1954 and 1955 and according to a letter from 1955 "half of them were allergic to $\mathrm{N}$-phenyl-1-naphthylamine." The individuals on this list constituted group C, overlapping group A with one subject; the others were exposed in other departments. The three groups and their exposure are described in table 1. 
Group A was composed of 78 women and 20 men. All could be fully identified, but nine had emigrated. Group B, ie, the reference group, contained 27 women and 8 men, of whom two women could not be identified. Group C constituted 23 men and 8 women, all of whom could be fully identified. The study comprised persons born between 1893 and 1942, and the distribution of person years in the different age classes is described in table 2.

All individuals were traced in the parish records through 31 December 1976. The cancer morbidity from 1958 to 1976 was determined from the Swedish Cancer Register. The expected incidence of cancer was calculated by multiplying the person-years of observation in each 5-a age-specific category by national genderand age-specific rates for the respective calendar years and summarizing over the cohorts (3). The Cancer Register had lists on all reported cases of cancer until 1976, but the rates for 1974-1976 were not yet available from this register and were therefore approximated by the rates for 1973. The expected mortality was calculated in the same manner, with the use of national gender- and age-specific rates from the Central Bureau of Statistics (12). The latency period was determined from the first year of exposure and accounted for in the calculations of expected incidences.

The potential influence of random variation on the difference between observed and expected incidence was described through the calculation of pvalues on the Poisson distribution; only two-tailed p-values below 0.05 are indicated.

\section{Exposure}

The main product of the company in question is bearing rings. To protect the bearing rings during transport and storage, they are covered with antirust oil be-

Table 1. Brief description of the studied populations and their exposure, 1954-1957.

\begin{tabular}{lll}
\hline Group & Selection criterion & Exposure, 1954-1957 \\
\hline A $(\mathrm{N}=98)$ & $\begin{array}{l}\text { Working in same packing department } \\
\text { as three original cancer cases, 1954- }\end{array}$ & $\begin{array}{l}\text { White spirit, mineral oil, lanolin, zinc } \\
\text { naphthenate, N-phenyl-1-naphthylamine } \\
+ \text { sodium nitrite }\end{array}$ \\
$\begin{array}{l}1957 \\
\text { B }(\mathrm{N}=33)\end{array}$ & $\begin{array}{l}\text { Working in another packing depart- } \\
\text { ment, 1954-1957 }\end{array}$ & $\begin{array}{l}\text { Mineral oil, vaseline, stearic acid + } \\
\text { sodium nitrite } \\
\text { White spirit, mineral oil, lanolin, zinc } \\
\text { naphthenate, N-phenyl-1-naphthylamine }\end{array}$ \\
\hline
\end{tabular}

Table 2. Distribution of person years in groups $A, B$ and $C$ allowing for a latency period of 5 a.

\begin{tabular}{|c|c|c|c|c|c|c|}
\hline \multirow{3}{*}{$\begin{array}{l}\text { Age class } \\
\text { (a) }\end{array}$} & \multicolumn{6}{|c|}{ Person years } \\
\hline & \multicolumn{2}{|c|}{ Group A } & \multicolumn{2}{|c|}{ Group B } & \multicolumn{2}{|c|}{ Group C } \\
\hline & Female & Male & Female & Male & Female & Male \\
\hline $\begin{array}{l}20-29 \\
30-39 \\
40-49 \\
50-59 \\
60-69 \\
70-79 \\
80-84\end{array}$ & $\begin{array}{r}31 \\
288 \\
425.5 \\
283.5 \\
96 \\
17.5 \\
0\end{array}$ & $\begin{array}{r}21 \\
82 \\
96.5 \\
57 \\
24 \\
4 \\
0\end{array}$ & $\begin{array}{r}5 \\
54 \\
132 \\
157 \\
86.5 \\
14 \\
0\end{array}$ & $\begin{array}{r}7 \\
29 \\
37 \\
30 \\
30 \\
11 \\
0\end{array}$ & $\begin{array}{r}0 \\
4 \\
36 \\
47 \\
29 \\
8 \\
0\end{array}$ & $\begin{array}{r}0 \\
12 \\
49.5 \\
78 \\
102.5 \\
75.5 \\
8\end{array}$ \\
\hline Total & $1,141.5$ & 284.5 & 448.5 & 144 & 124 & 325.5 \\
\hline $\begin{array}{l}\text { Total number } \\
\text { of persons }\end{array}$ & 78 & 20 & 25 & 8 & 8 & 23 \\
\hline
\end{tabular}


fore being packed. To make the antirust oil thin and easy to apply, it was usually mixed with white spirit, which evaporated from the bearing rings at room temperature during about $1 \mathrm{~d}$ before the packing began. The anticorrosive protection of the bearing rings was increased with a paper containing sodium nitrite. Before the beginning of the 1970s the packing was done by hand and mostly by women. They took the bearing ring, which was covered with antirust oil, and put it on a sheet of paper and wrapped it by hand. This procedure was done during the whole workday. The packing was not dusty, but there was much skin contact with the antirust oil and packing paper. The workers never used gloves, and, when the paper with sodium nitrite was used, many women got yellow fingers and hands. The yellow color could not be washed away.

Between 1954 and 1957 the packing paper and the wrapping procedure were the same in the packing department of group $\mathrm{A}$ and $\mathrm{B}$, but $\mathrm{N}$-phenyl-1-naphthylamine was not present in the latter department. The paper contained $5-7 \%$ sodium nitrite and was stabilized with sodium carbonate to a $\mathrm{pH}$ of 8 . The paper had paraffin on both sides. Today the packing paper has mostly been replaced by polyethylene, and the packing is automated.

Over the years there have been different procedures for applying the antirust oil, and the composition of the antirust oils has varied. The application procedures and compositions have been obtained from the company's files and can be described as follows.

From about 1935 to 1954 bearing rings in all departments were immersed in heated $\left(90-120^{\circ} \mathrm{C}\right)$ mineral oil with stearic acid and vaseline and dried before being wrapped. After 1954 the process differed between the various departments. As already mentioned, the packing department of group A used a special antirust oil containing N-phenyl-1-naphthylamine, among other substances, from 1954 to 1957 (table 3 ). The oil was not heated. From 1957 to 1962 the antirust oil contained solventrefined mineral oil, stearic acid, and white spirit. From 1962 to 1971 the oil contained solvent-refined mineral oil, stearic acid, white spirit, barium sulfonate, lanolin and zinc naphthenate. In the packing department of group B a heated mineral oil with stearic acid and lanolin was used until 1961. After 1961 this group used the same antirust oils as group A.

Antirust oil was also used in other departments of the company for protecting unfinished products. It was with this process that all but one of the persons in group $\mathrm{C}$ came in contact with the antirust oil that contained N-phenyl-1-naphthylamine (table 3 ).

\section{Results}

Twelve women but no men in group A were found in the Cancer Register. One more woman was, in fact, found in the Register but was shown not to have had cancer when the diagnosis was checked in the medical records. She had had an adenoma of the thyroid which had been primarily diagnosed as cancer after a fineneedle biopsy but was correctly diagnosed in a pathologicoanatomic examination (PAD) after an operation. This case has not been included in the figures, which, in principle, understimate the risk since the rates used for calculating expected incidence might contain other similar misclassifications. All cancers were diagnosed between 1964 and 1973, and the cancer morbidity for the women was considerably increased (tables 4 \& 5). Mortality was also increased for the women, but the entire increase was explained by an increased mortality from cancer. As shown in table 5 , there was no dominant cancer site. If a latency period of at least $10 \mathrm{a}$ is considered, there was 11 cases of cancer vs 3.1 expected (782 person-years at observation; $\mathrm{p}<0.001)$.

Table 3. Composition of the investigated antirust oil used by groups $A$ and $C$.

\begin{tabular}{lc}
\hline Substance & Concentration \\
\hline White spirit & $50.0 \%$ \\
Mineral oil (acid refined) & $16.5 \%$ \\
Lanolin & $16.5 \%$ \\
Zinc naphthenate & $16.5 \%$ \\
N-phenyl-1-naphthylamine & $0.5 \%$ a \\
\hline
\end{tabular}

a Originally the content was $2 \%$, but the concentration was lowered after a few months because of skin problems 
In addition to these 98 persons (group A), the personnel register also contained two engineers who had worked in the same department. They are not included in the figures since wrapping was not their main work. They both died in 1977, one from cancer of the thyroid and the other from cancer of the pancreas, at the age of 71 and 54 a, respectively. An inter- viewed foreman said that these two engineers had sometimes also wrapped bearing rings but apparently to a much less extent than the women.

In groups $\mathrm{B}$ and $\mathrm{C}$ there was no increased cancer morbidity or increased mortality (table 4). Two of the workers in group $\mathrm{C}$ developed cancer of the bladder, one of whom (a woman) was also included

Table 4. Morbidity from cancer and mortality in the different groups allowing for a latency period of at least 5 a.

\begin{tabular}{|c|c|c|c|c|}
\hline & Observed & Expected & $\begin{array}{l}\text { Rate } \\
\text { ratio }\end{array}$ & $\begin{array}{l}95 \% \text { confidence } \\
\text { interval of the } \\
\text { rate ratio } c\end{array}$ \\
\hline \multicolumn{5}{|l|}{ Group A } \\
\hline \multicolumn{5}{|l|}{ Women (1,141.5 person-years) } \\
\hline Morbidity from cancer & $12 * *$ & 3.9 & 3.1 & $1.6-5.4$ \\
\hline Mortality from all causes & 8 & 4.3 & 1.9 & $0.8-3.7$ \\
\hline Mortality from cancer & $6^{*}$ & 1.7 & 3.5 & $1.3-7.6$ \\
\hline \multicolumn{5}{|l|}{ Men (284.5 person years) } \\
\hline Morbidity from cancer & 0 & 0.7 & 0 & \\
\hline Mortality from all causes & 1 & 1.8 & 0.6 & \\
\hline Mortality from cancer & 0 & 0.4 & 0 & \\
\hline \multicolumn{5}{|l|}{ Group B (592.5 person-years) } \\
\hline Morbidity from cancer & $4 \mathrm{a}$ & 2.0 & 2 & \\
\hline Mortality from all causes & 1 & 4.4 & 0.2 & \\
\hline \multicolumn{5}{|l|}{ Group C (449.5 person-years) } \\
\hline Morbidity from cancer & $4 \mathrm{~b}$ & 3.8 & 1.1 & \\
\hline Mortality from all causes & 9 & 10.0 & 0.9 & $0.4-1.7$ \\
\hline \multicolumn{5}{|c|}{$\begin{array}{l}\text { a Cancer of the collum of the uterus, unclassified tumor of inguen, cancer of the pancreas, and } \\
\text { cancer of the breast. }\end{array}$} \\
\hline \multicolumn{5}{|c|}{ b Cancer of the stomach, cancer of the pleurae, and two cases of cancer of the bladder. } \\
\hline \multicolumn{5}{|c|}{$\begin{array}{l}\text { Cancer of the stomach, cancer of the pleurae, and two cases of cancer of the bladder. } \\
\text { c Confidence interval due to a Poisson distribution (2). Only intervals with expected or observed } \\
\text { values of more than } 5 \text { are indicated. }\end{array}$} \\
\hline \multicolumn{5}{|l|}{$* p<0.05, * * p<0.005$} \\
\hline \multirow{2}{*}{\multicolumn{5}{|c|}{$\begin{array}{l}\text { Table 5. Morbidity from cancer among women exposed to an antirust oil (table 2) and sodium } \\
\text { nitrite at some time between } 1954 \text { and } 1957 \text {. Figures within parentheses are the International Clas- } \\
\text { sification of Diseases numbers ( } 8 \text { th revision). }\end{array}$}} \\
\hline & & & & \\
\hline Site & $\begin{array}{l}\text { Age at } \\
\text { diagnosis } \\
\text { (a) }\end{array}$ & & & $\begin{array}{l}\text { Latency period } \\
\text { (a) }\end{array}$ \\
\hline Colon (153) & 65 & & & 18 \\
\hline Breast (174) & 60 & & & 17 \\
\hline Collum of the uterus (180) & 49 & & & 9 \\
\hline Collum of the uterus (180) & 46 & & & 10 \\
\hline Collum of the uterus (180) & 38 & & & 10 \\
\hline Corpus of the uterus (182) & 60 & & & 18 \\
\hline Ovary (183) & 49 & & & 12 \\
\hline Ovary (183) & 56 & & & 19 \\
\hline Bladder (188) & 66 & & & 12 \\
\hline Brain (191) & 47 & & & 11 \\
\hline Thyroid (193) & 38 & & & 10 \\
\hline Reticulosarcoma (200) & 57 & & & 18 \\
\hline
\end{tabular}


in group A. (See the preceding discussion of the overlapping of groups $\mathrm{A}$ and $\mathrm{C}$ by one individual.)

\section{Discussion}

Epidemiologic investigations prompted by observations of several cases often entail difficulties with the interpretation of the results since clusters may arise by chance. In this situation, a suspicion of a causal association was aroused by three cases, but, even if they are excluded, the increased incidence of cancer among women was formally significant ( 9 observed vs 3.9 expected; $\mathrm{p}<0.05$ ).

Since no increased incidence was observed in group B or C, a preliminary conclusion is that, if the increase in group $A$ is caused by the work environment and not by chance, it must be due to some specific factor operating in group $\mathrm{A}$. The wrapping was mainly done by women, and the men employed in the department had other tasks to a great extent, eg, transport, which might explain why women were predominantly affected. Group C presumedly had a short exposure to antirust oil since they became sensitized. Groups $\mathrm{B}$ and $\mathrm{C}$ were small, and the outcome of these groups must therefore be interpreted as "nonpositive" rather than negative.

All groups have some similarities with respect to exposure, but the difference between the groups is the exposure to $\mathrm{N}$ phenyl-1-naphthylamine (A \& C) and sodium nitrite (A \& B). If the increased incidence of cancer was not caused by chance, we think that N-phenyl-1-naphthylamine is the most probable agent or, alternatively $\mathrm{N}$-nitroso-N-phenyl-1-naphthylamine, as the presence of nitrite in the wrapping paper might result in the formation of this compound.

We have found no epidemiologic study concerning persons only exposed to $\mathrm{N}$ phenyl-1-naphthylamine. However, Nphenyl-1-naphthylamine is sometimes used in the rubber industry, and investigations of workers in the rubber industry have shown an increased incidence of cancer although many compounds might contribute to the cancer hazards among rubber workers $(10,11)$. The chemical similarity between N-phenyl-1-naphthylamine and 2-naphthylamine, a well-known car- cinogen of the bladder (15), should increase the suspicion that N-phenyl-1naphthylamine may be a carcinogen. $\mathrm{N}$ phenyl-1-naphthylamine may also contain 2-naphthylamine as an impurity, and two persons in group $\mathrm{C}$ developed cancer of the bladder, which is somewhat remarkable in this small group.

One might also speculate on a combined effect of sodium nitrite and N-phenyl-1naphthylamine since there was no increased incidence of cancer in group B or C (table 4). It is well known that secondary amines and sodium nitrite can form $\mathrm{N}$-nitrosoamines (5). Sodium nitrite and $\mathrm{N}$-phenyl-1-naphthylamine might form $\mathrm{N}$ nitroso-N-phenyl-1-naphthylamine. No data on the testing of the carcinogenic properties of this substance have been found, but several $\mathrm{N}$-nitrosoamines are known to be carcinogenic in animals (6).

If the increased incidence of cancer was caused by the antirust oil and/or the paper, the mode of exposure was probably through the skin, as the process was not dusty and the vapor pressure of the used substances was rather low at room temperature. We have not found any studies of skin absorption of N-phenyl-1naphthylamine. However, a rather similar substance like 2-naphthylamine is readily absorbed through the skin (13). It is therefore probable that N-phenyl-1-naphthylamine and its degradation product 1-naphthylamine also are absorbed through the skin. The skin absorption may also have been enhanced by fat-soluble substances such as organic solvents.

Latency periods of more than 10 a are often reported for tumors induced by chemicals $(1,14)$. In this study the latency periods ranged between 9 and 19 a from the start of exposure, ie, an elapse of time which is rather reasonable for a causal connection to be ascertained. Animal experiments have shown that a longer latency period is to be expected if the exposure is low (9). The exposure time for these women was short, but the exposure might have been high if there was considerable skin absorption. It should also be noted that theoretically the longest possible latency period for these groups is 22 a.

There were different sites of cancer, which somewhat contradicts a causal connection between a single substance and 
the increased incidence of cancer. However some of the cases of cancer should be expected to occur even if there had been no causative agent in this work environment; there may have also been variability by chance.

Animal experiments have shown that skin application of mineral oils causes skin tumors. The antirust oil contained mineral oils which can cause human skin cancer (7). However, epidemiologic studies of men exposed to mineral oils have not shown any increased incidence of cancer of other sites in this company (8), perhaps with the exception of gastrointestinal cancers; similar experiences have been obtained by others (4). Both the studies referred to contained persons with a much heavier and longer exposure to mineral oils by skin contact and through the inhalation of oil mist than the exposure of the women in group A. The women in group A were mainly exposed through skin contact, but no skin tumors occurred, a finding which makes the mineral oils much less probable as a causative agent than N-phenyl-1naphthylamine or its corresponding $\mathrm{N}$ nitrosoamine.

To sumarize, we think that, if the increased incidence of cancer among the women in group A is not caused by chance, the most probable causative agent is $\mathrm{N}$ phenyl-1-naphthylamine or its $\mathrm{N}$-nitroso derivative. This substance is still used in some cutting oils, hydraulic oils, and sometimes in the rubber industry. As this study leads to a suspicion that the relatively widely used substance, N-phenyl-1-naphthylamine, may be a carcinogen, further epidemiologic and toxicologic studies are important.

\section{Acknowledgment}

We are indebted to $\mathrm{Dr} \mathbf{E}$ Brittebo, Prof $O$ Axelson and $\mathrm{Dr} G$ Thiringer for their discussions about the manuscript.

Received for publication: 11 February 1981

\section{References}

1. Armenian HK, Lilienfeld AM. The distribution of incubation periods of neoplastic diseases. Am j epidemiol 99 (1974) 92-100.

2. Bailar JC, Ederer F. Significance factors for the ratio of a Poisson variable to its expection. Biometrics 20 (1964) 639-643.

3. Cancer Registry, National Board of Health and Welfare. Cancer incidence in Sweden 1958, 1959, ‥1972, 1973. Stockholm, 1958, $1959, \ldots 1973$.

4. Decoufle P. Further analysis of cancer mortality patterns among workers exposed to cutting oil mists. $J$ natl cancer inst 61 (1978) 1025-1030.

5. Douglass ML, Kabacoff BL, Anderson GA, Cheng MC. The chemistry of nitrosamine formation, inhibition and destruction. $J$ soc cosmet chem 29 (1978) 581-606.

6. Druckery $\mathrm{H}$, Preussman $\mathrm{R}$, Ivankovic $\mathrm{S}$, Schmäl D. Organotrope carcinogena Wirkungen bei 65 verschiedenen $\mathrm{N}$-nitrosoVerbindungen in BD-Ratten. Z Krebsforsch 69 (1967) 103-201.

7. Emmet EA. Occupational skin cancer: A review. J occup med 17 (1975) 44-49.

8. Järvholm B, Lillienberg $L$, Sällsten $G$, Thiringer $G$, Axelson $O$. Cancer morbidity among men exposed to oil mist in the metal industry. $J$ occup med 23 (1981) $333-337$.

9. Jones HB, Grendon A. Environmental factors in the origin of cancer and estimation of the possible hazard to man. Food cosmet toxicol 13 (1975) 251-268.

10. McMichael AJ, Andjelkovich DA, Tyroler HA. Cancer mortality among rubber workers: An epidemilogic study. Ann ny acad sci 271 (1976) 125-137.

11. Monson RR, Nakano KK. Mortality among rubber workers: I. White male union employees in Akron, Ohio. Am $\mathrm{j}$ epidemiol 103 (1976) 284-296.

12. National Central Bureau of Statistics. Cause of death $1958,1959, \cdots 1976$. Stockholm 1958, 1959, $\cdots 1976$.

13. Patty FA, ed. Industrial hygiene and toxicology. Second ed. Interscience Publishers, New York, NY 1963, p 2144.

14. Selikoff IJ. Recent perspectives in occupational cancer. Ambio 4 (1975) 14-17.

15. Zenz C, ed. Occupational medicine, principles and practical application. Year Book Medical Publishers, Chicago, IL 1975, pp $855-857$. 